\title{
Tuba Root (Derris elliptica Benth.) Biopesticide Potential Assay to Control Brown Planthopper (Nilaparvata lugens Stal.) on Rice Plant (Oryza sativa L.)
}

\author{
Rusli Rustam ${ }^{\mathrm{a},}$, Hafiz Fauzana ${ }^{\mathrm{a}}$, Nurjayanti ${ }^{\mathrm{b}}$, Rachmad Saputra ${ }^{\mathrm{a}}$ \\ a Department of Agrotechnology, Faculty of Agriculture, Riau University, Pekanbaru, Riau, 28293, Indonesia \\ ${ }^{b}$ Agriculture Science Master Program, Faculty of Agriculture, Riau University, Pekanbaru, Riau, 28293, Indonesia

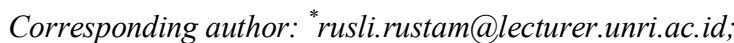

\begin{abstract}
Brown planthopper (Nilaparvata lugens Stal.) is one of rice plants' pests that attack from the nursery to the harvest stage. Controls carried out by farmers generally use synthetic insecticides. Reducing the impact caused by synthetic insecticides, an alternative that can be used to controlling the brown planthopper is by using botanical insecticide tuba root. Tuba root plants have been widely reported to control pests and contain the active ingredient rotenone. Rotenone works as a stomach poison and selective. This study aims to examine the ability of tuba root plant parts extracts (leaves, branches, and roots) with organic solvents to control brown planthopper pests in rice plants. The study was conducted in February-April 2019 at the Plant Pest Laboratory, Faculty of Agriculture, University of Riau. The study was conducted experimentally using a Completely Randomized Design (CRD) with three treatments and six replications to obtain 18 experimental units. The tuba root plant trial test consists of 3 levels: root extract, branch extract, and leaf extract with organic solvents. The parameters observed were the time of death of brown planthopper (hour), lethal meantime (LT50) (hour), daily mortality (\%), and total mortality (\%). The results showed that the application of root extract caused an initial death of 2.33 hours after application, LT50 17.33 hours after application with a total mortality rate of 100\%. Application of botanical insecticide tuba root is effective for controlling brown planthopper pests in rice plants because it causes the death of brown planthopper above $80 \%$.
\end{abstract}

Keywords - Botanical insecticide; rice plant; Nilaparvata lugens Stal.; Derris elliptica Benth.

\section{INTRODUCTION}

Rice plants are one of the primary food sources for Indonesia society. The need for rice every year continues to increase, along with increasing the population. Riau is one of the rice-producing provinces in Indonesia. According to the Central Statistics Agency of Riau Province [1], the harvested rice area in Riau Province in 2018 reached 93.755 ha with a productivity of 3.90 tons/ha and production of 365.293 tons of milled dry grain.

The problems faced by farmers to produce high grain production are increasingly diverse. Some of the factors that become a problem include the narrowed area of land due to rice fields' conversion to plantations and the pest attacks. One of the pests that attack rice plants is brown planthopper (Nilaparvata lugens Stal.).

Brown planthopper is the main and important insect pest of rice in Indonesia. Brown planthopper populations in Asia are grouped into three biotypes: East Asian, Southeast Asian, and South Asian. Brown planthopper is found in Indonesia belongs to the Southeast Asian biotype that is found in the Philippines, Thailand, Myanmar, Laos, Cambodia, and Malaysia [2].

Brown planthopper attack rice plants in all stages of growth, from seeding to harvest. These pests damage directly by piercing and sucking plant fluids [3] from phloem tissue [4], thereby reducing chlorophyll and leaf protein content and reducing the rate of photosynthesis [5]. Plants that are attacked become yellowed, withered and eventually cause symptoms of hopper burn or dry death [6].

Brown planthopper can cause very high damage under field conditions in a given time. Its cause of the BPC capable of causing maximum damage per individual insect and high fecundity. Brown planthopper's third and fourth instar nymphs have been reported to be more devastating among the different life stages [2]. Brown slope is also a vector of the 
spread of grass dwarf and empty dwarf disease whose damage can be greater than the attack of brown planthopper itself [7], [8].

The attack of 4 brown planthopper imago/rice grove during the period of 30 days can reduce yield by $77 \%$, during pregnancy reduces yield by $37 \%$ and fruit ripening period decreases yield by $28 \%$ [9]. Brown planthopper attacks in Indonesia in 2010 and 2011 reached 137,768 ha and 218,060 ha. Damages include crop failure ("puso"), causing an average yield loss of 1-2 tons/ha [6]. While the area of brown planthopper attacks, especially in Riau Province in 2015, reached 77.2 ha [10]. Therefore, it is necessary to control the brown planthopper pest.

Common control by farmers to suppress the population of brown planthopper is to use chemical insecticides. However, the use of chemical insecticides continuously and unwise makes a negative impact. Adverse impacts include environmental pollution, secondary pest outbreaks, natural enemy death, resistance, and resurgence [11].

Sutrisno [12] reported that brown planthopper in Indonesia has been resistant to BPMC, carbofuran, MIPC, and imidacloprid insecticide. Melhanah et al. [13] also reported that brown planthopper from Central Java Province, selected in the laboratory for four generations, was resistant to fipronil chemical insecticide. Imidacloprid chemical insecticide also triggers the resistance of brown planthopper 13-234 times the recommended dose. Sublethal doses of imidacloprid tend to increase the number of brown planthopper populations in the field [14]. Nanthakumar et al. [15] also stated that the brown planthopper resurgence triggers a shorter period of development and growth of brown planthopper and an increase in the proportion of macropterous forms. Given its damaging effects, the use of chemical insecticides to control brown planthopper pests must be reduced. Another alternative in controlling brown planthopper pests that are more environmentally friendly is needed, namely by using botanical insecticides.

The botanical insecticide is an insecticide whose primary ingredients are from plants. Botanical insecticides, which are made from active secondary metabolites of plants, can provide one or more biological activities, influence aspects of physiology and pest behavior, and meet the requirements for use in controlling plant pests [16]. One type of plant that has potential as a source of botanical insecticide is the tuba root plant (Derris elliptica Benth.) [17].

Tuba root plants belong to the type of Fabaceae (Leguminosae) [18] whose leaves, roots, and branches can be botanical insecticides. A plant's effectiveness as a source of botanical insecticide is influenced by one part of the plant [19]. Different parts of plants have different toxicity to pests. Active compounds contained in tubal roots include dehydrotenone, deguelin, elliptone, and rotenone [20]. Rotenone levels are distributed in all parts of tuba root plants, such as branches, stems, leaves, and most roots [21], [22]. Rotenone compounds contained in tuba roots are $0.3-12 \%$ [23]. Rotenone compounds are widely reported in agriculture as an insecticide because they are a contact poison and stomach poison against insect pests [23], [24].

Rotenone active ingredients work as stomach poisons and selective contact poisons against insects [23]. The mechanism of insecticide stomach poison is by killing the target insect by entering into digestion through food that is eaten. Insecticides enter the digestive organs of insects and are absorbed by the intestinal wall. They are transplanted into the nerve center of insects and respiratory organs and poison stomach cells [25].

Several research results have been reported about the effectiveness of tuba root extracts with water solvents in controlling pests that attack several cultivated agricultural commodities. Test application of tuba root extract with a concentration of $1 \mathrm{~g} / 1$ of water can cause mortality of $100 \%$ snail pests [26], tuba root concentration of $30 \mathrm{~g} / 1$ of water causes total mortality of Paracocus marginatus white bug nymphs $95 \%$ [27]. The application of $0.6 \%$ tuba root extract effectively controlled Aphis glycines aphids by $91.66 \%$ [28]. Tuba root extract with a concentration of $10 \mathrm{~g} / 1$ of water can control the brown planthopper pest in rice plants by $90 \%$ in the laboratory [29]. Meanwhile, a study on tuba root extract with organic solvents has been conducted by Kinansi et al., showing that ethanol extract of tuba root is effective in killing $50 \%$ of Periplaneta americana 6,505 hours at a concentration of $3 \mathrm{~g} / 100 \mathrm{ml}$ of water [30].

The botanical insecticides were made by the maceration method, which aims to get the plant extracts that usually use certain solvents, one of which is methanol. The use of methanol solvents aims to accelerate the release of extractive substances contained in these plants. Atun states that methanol has the advantage of having a lower boiling point to evaporate at lower temperatures [31] quickly.

Research on the utilization of tuba root as a botanical insecticide with water solvents has been widely reported. However, tuba root biopesticides with organic solvents to control the brown planthopper pest in lowland rice plants have not been widely reported. Therefore it is necessary to conduct studies and research related to the potential of tuba root (Derris elliptica Benth.) as a botanical insecticide to control the brown planthopper (Nilaparvata lugens Stal.) in rice plants (Oryza sativa L.).

\section{MATERIAL AND METHOD}

The study was conducted at the Pest Laboratory of the Faculty of Agriculture, University of Riau, Pekanbaru City, Riau Province. This research was conducted for three months, from February to April 2019. The materials used are rice seeds of IR-42 variety, brown planthopper imago, manure, extracts of tuba root plants (from leaves, branches and roots), methanol, water, sterile aquadest, and $1000 \mathrm{ml}$ volume plastic cups. The tools used in this study are analytical scales, rotary evaporator, thermohygrometer, stir bar, Whatman filter paper, container size $26 \times 20 \mathrm{~cm}, 500 \mathrm{ml}$ hand sprayer and $1000 \mathrm{ml}$ Erlenmeyer, label paper, aspirator, knife, filter, scissors, gauze, roll tissue, flashlight, camera, and stationery.

The study was conducted experimentally using a Completely Randomized Design (CRD) with three treatments and six replications to obtain 18 experimental units. The treatment, including tuba leaf extract, tuba root extract, and tuba branches extract.

\section{A. Research Implementation}

1) Feed Provision: The rice seed used is IR-42 variety obtained from the Indonesian Center for Rice Research in Subang, West Java. Seeding of rice seeds is carried out in 26 x $20 \mathrm{~cm}$ plastic containers. Rice seeds are planted in a 
container filled with water until it is moist, then left until the rice seeds germinate. Seeding is carried out for 14 days. 14day-old rice seedlings that already have 3-4 leaves, ready to be used as brown plant hopper feed [32].

2) Propagation of brown planthopper: Brown planthopper imago was taken from the affected paddy rice plant in Jaya Pura Village, Bunga Raya District, Siak Regency, Riau Province. Brown planthopper was taken directly at the base of the stem of rice plants using an aspirator (Fig. 1). Brown planthopper taken from the field is propagated in a plastic container that has contained IR-42 variety of rice seeds aged 14 days after seedling. Rice seedlings are used as brown plant hopper hosts and maintained to obtain offspring until the amount is sufficient for the treatment of as many as 180 birds; water is added every day to taste. Propagation of brown planthopper is done until the 1-day old imago is obtained. Propagation is carried out until the F2 generation (within 2 months).

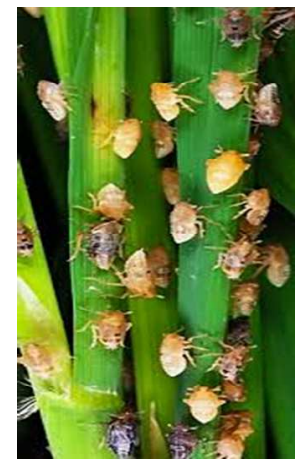

Fig. 1 Brown planthopper imago in the field

3) Making tuba root extracts with organic solvents: Tuba root plants which are used as sources of extracts are leaves, roots and twigs taken from community gardens in Tapung District, Kampar Regency, Riau. Leaves, roots and branches took to the Plant Pest Laboratory, then dried for 1 week. The dried leaves, roots, and branches are then cut into small pieces with a size of $\pm 2 \mathrm{~cm}$ and mashed using a blender. The fine tuba root flour is filtered using a $0.5 \mathrm{~mm}$ mesh sieve (Fig. 2). Furthermore, the obtained tubal root flour is stored.
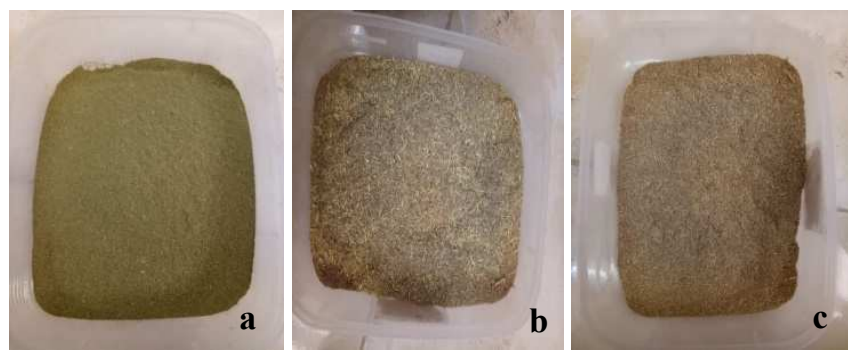

Fig. 2 Tuba root plant flour from leaf tissue (a), branch (b) and root (c)

Tuba root powder extraction was carried out using methanol (polar) solvent with maceration method. Extraction process by maceration method, each extract of tuba root plant parts (leaves, twigs and roots) was put into the Erlenmeyer containing flour and methanol at a ratio of 1:4 and stirred using magnetic stirrers for 6 hours, then macerated (soaking) for 24 hours [33]. Next, filtered using a Buchner funnel based on filter paper and the filtrate was evaporated using a rotary evaporator at a temperature of $78^{\circ} \mathrm{C}$ so that $100 \%$ of tuba root extract was obtained. The extraction results were further diluted using distilled water to obtain each treatment of tubal root concentration (Fig. 3). The extraction process can be seen on the flowchart (Fig 4).
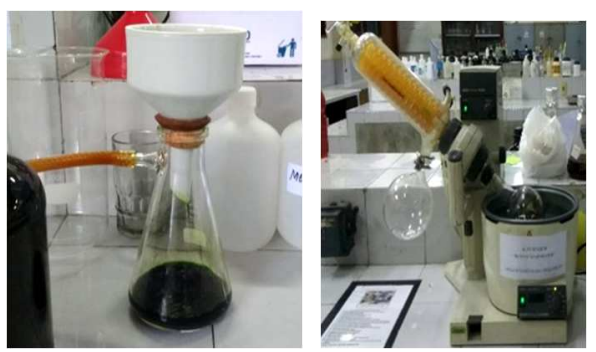

Fig. 3 The process of making extracts from tuba root plant flour

4) Application of tuba root extract treatment from different plant tissues: Application of extracts of tuba root plant parts of $1 \%$ each is made 12 hours after the brown planthopper imago infestation. Before making an application, first, do a calibration. Calibration is done by filling a $100 \mathrm{ml}$ hand sprayer with water until it is full, then spraying it evenly on the rice plants. The amount of water left in the hand sprayer is calculated. The volume of water before spraying is reduced by the volume of water left in the hand sprayer to obtain the spray volume. Calibration was repeated 3 times and averaged (Fig. 5a). Each extract part of the tuba root plant according to the treatment concentration of $1 \%$ with a spray volume of 4 $\mathrm{ml}$ was sprayed on all parts of the rice plant that had been infested with brown planthopper in the laboratory (Fig. 5b). After the application is made, it is observed every 1 hour for 72 hours.

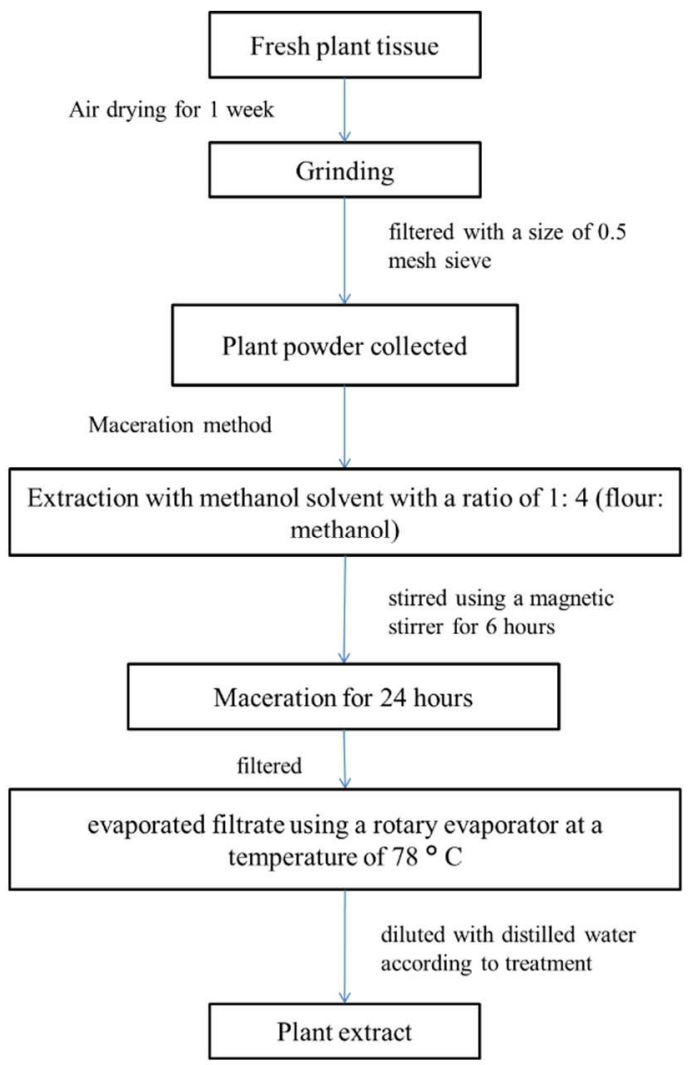

Fig. 4 Flowchart of tuba root extracts 

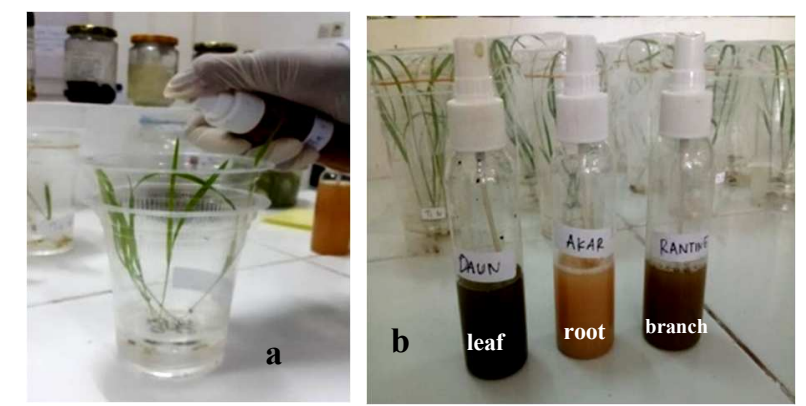

Fig. 5 Stages of implementing tuba root insecticide application. a) Calibration of the treatment and b) $1 \%$ concentration of the treatment

\section{B. Observation Parameters}

1) First time of death of brown planthopper (hour): Observations were made by calculating the time needed to turn off the earliest brown planthopper. Observations are made 1 hour after application and continued every 1 hour later.

2) Lethal meantime (LT50) (hour): Observations were made by calculating the time needed for each treatment to kill $50 \%$ of the brown planthopper imago population. Observations were made every 1 hour after treatment was given up to $50 \%$ of the population of brown planthopper imago that died from each experimental unit.

3) Daily mortality (\%): Observations were made by counting the number of brown planthopper imago that died every day after being given treatment. According to Natawigena [34] the percentage of daily mortality can be calculated using the following formula:

$$
M H=\frac{a-b}{a} \times 100 \%
$$

Note:

$$
\begin{array}{ll}
\mathrm{MH} & =\text { Percentage of daily mortality } \\
\mathrm{a} & =\text { Number of brown planthopper imago treated } \\
\mathrm{b} & =\text { The number of brown planthopper living }
\end{array}
$$

4) Total Mortality (\%): Observations were made by calculating the percentage of the total population of brown planthopper imago that died until the end of the observation. According to Natawigena [34] the percentage of total mortality can be calculated using the following formula:

$$
M T=\frac{c}{d} \times 100 \%
$$

$$
\begin{array}{ll}
\text { Note: } & \\
\text { MT } & =\text { Percentage of total mortality } \\
\text { c } & =\text { The number of died brown plant hopper imago } \\
\text { d } & =\text { Number of brown planthopper imago treated }
\end{array}
$$

\section{Data Analysis}

Observational data were analyzed statistically using Analysis of variance (ANOVA) with F test at 5\% alpha level. If the treatment has a significant effect followed by further testing, the Least Significant Difference (LSD).

\section{RESULT AND DISCUSSION}

\section{A. First time of Death of Brown Planthopper (Hour)}

The results of variance showed that the treatment of botanical insecticides from several parts of the tuba root plant significantly affected the initial time of death of brown planthopper in rice plants in the laboratory. LSD further test results at the level of 5\% can be seen in Table 1 .

TABLE I

The Average First Time of DeAth Of Brown Planthopper After APPLICATION OF BOTANICAL INSECTICIDE FROM SEVERAL PARTS OF THE TUBA ROOT PLANT (HOURS)

\begin{tabular}{cc}
\hline Part of Tuba Root Plant & Average (hour) \\
\hline Root & $2.33 \mathrm{a}$ \\
Branch & $4.83 \mathrm{~b}$ \\
Leaf & $7.33 \mathrm{c}$ \\
\hline
\end{tabular}

Note: The number on the lane followed by lowercase letters are not significantly different according to the LSD test at the 5\% level.

Table 1. shows that the treatment of botanical insecticides, tubal roots, roots, branches, and leaves caused the initial death of brown planthopper to be significantly different from all treatments. Treatment with botanical insecticide tubal roots of the roots, branches, and leaves can show an influence on the initial death of brown planthopper with a time span of 2.37.33 hours. This shows that botanical insecticides on the roots of the fallopian roots, branches, and leaves can kill brown planthopper at different times.

Botanical insecticide treatment of tubal roots of the root causes the early death of brown planthopper, which occurs at the fastest 2.33 hours after application and is significantly different from the treatment of tuba roots in the branches and leaves. Whereas in the treatment of the branch, the first death occurred at 4.83 hours after application and was significantly different from the treatment of the leaves with an initial death of 7.33 hours after application. Botanical insecticides of the root part give a faster influence on killing brown planthopper. This is presumably because secondary metabolites contained in botanical insecticides in the tuba roots have more roots than in the leaves and branches. According to Kuncoro [21], rotenone levels are spread in all parts of the tuba root plant, such as branches, stems, leaves, and roots. However, most are in the roots [22]. Rotenone is chemically classified into the flavonoid group [25]. In addition to rotenone, tubal roots also contain deguelin, toxicarol, alkaloids, saponins, and polyphenols [20]. Rotenone compounds contained in tuba roots are $0.3-12 \%$ [23].

Based on the results of research that has been done, it can be seen morphological changes and changes in the behavior of brown planthopper imago after being applied with the botanical insecticide tuba roots. After the application of tubal root botanical insecticides, the initial symptoms of brown planthopper death are inactive insects such as before being treated if touched will fly and fall, the brown planthopper imago that died of changing color to black. According to Kardinan [35], evaluating the effects of insecticide poisoning on insects is to see the physical response and behavior of test insects after contact with the applied insecticide. In this study, secondary metabolites in tubal root botanical insecticides can kill brown planthopper as contact poisons and stomach poisons, namely through spraying on rice plants and brown planthopper. Kardinan [23] supports this by showing that tubal roots are a contact poison and stomach poison against insect pests.

\section{B. Lethal Mean Time (LT50) (hour)}

The observation of lethal meantime (LT50) after analysis of variance showed that the treatment of botanical insecticides 
from several parts of the tuba root plant significantly affected the time needed to kill brown planthopper pests by as much as $50 \%$. BNT further test results at the level of $5 \%$ can be seen in Table 2.

TABLE II

Lethal Mean Time (LT50) Average of Brown Planthopper After THE APPLICATION OF BOTANICAL INSECTICIDES FROM SEVERAL PARTS of THE TUBa RoOT Plant

\begin{tabular}{cc}
\hline Part of Tuba Root Plant & Average (hour) \\
\hline Root & $17.33 \mathrm{a}$ \\
Branch & $26.00 \mathrm{~b}$ \\
Leaf & $33.50 \mathrm{c}$ \\
\hline
\end{tabular}

Note: The number on the lane followed by lowercase letters are not significantly different according to the LSD test at the 5\% level.

Table 2 shows that botanical insecticides from different parts of the tuba root significantly affect the lethal mean time (LT50) of brown planthopper. The treatment of botanical insecticides on the roots of the tuba causes lethal mean time (LT50) in brown planthopper with a range of 17.33-33.50 hours after application. Botanical insecticides from the root part are the fastest treatment in killing $50 \%$ of brown planthopper (17.33 hours after application) and significantly different from other treatments. Botanical insecticides from the branches part are significantly different from leaves, with lethal mean time (LT50) of brown planthopper 26.00 and 33.50 hours after application.

The time needed for botanical insecticide tubal roots in the root to kill $50 \%$ brown planthopper faster than other treatments. This is presumably because the amount of secondary metabolite compounds found in root extracts is higher than that found in branches and leaves so that the occurrence of brown planthopper death is as much as $50 \%$. Martono et al., [36], stated that the effectiveness of a plantbased ingredient used as botanical insecticides is very dependent on the material used. So that the high secondary metabolites contained in the root section cause the faster of brown planthopper lethal mean time.

\section{Daily mortality (\%)}

The observations results on the percentage of brown planthopper daily mortality with botanical insecticides in different parts of the tuba root plant cause different mortality. Daily mortality of brown planthopper can be seen in Figure 6.

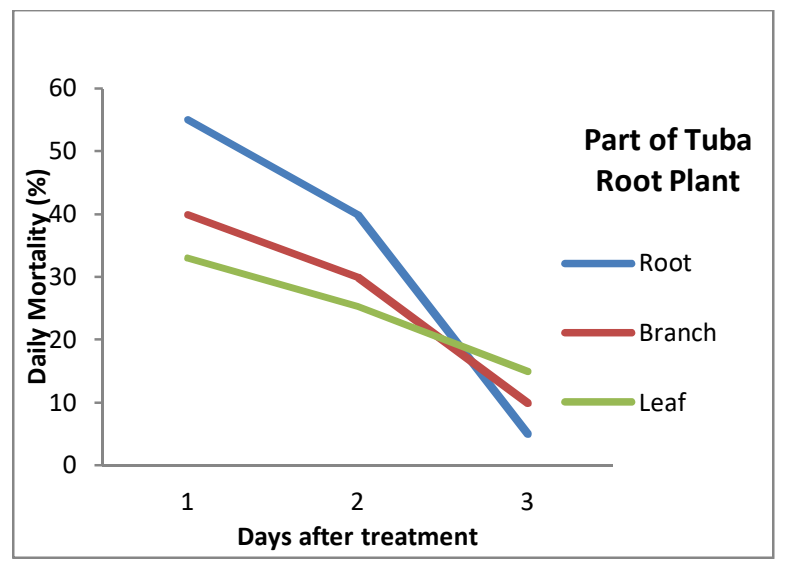

Fig. 6 Daily mortality of brown planthopper after application of botanical insecticides from tuba root plant parts
Figure 6 shows that the application of botanical insecticides from the roots part causes daily mortality of brown planthopper, which is different in each treatment. Daily mortality in the application of tubal root insecticide can kill brown planthopper in the range of $33-55 \%$ on the first day, on the second day the range is $25.33-40 \%$ and on the third day there is a decrease of $5-15 \%$. Observation on the first day on the treatment of botanical insecticide from the root part can kill the brown planthopper by 55\%, followed by treatment of branches and leaves that can cause mortality of $40 \%$, and $33 \%$, respectively.

The difference in daily mortality is due to different parts of the tuba root plant that used as the source of botanical insecticides. Botanical insecticide treatment from the roots part can cause the highest daily mortality on the first day. This is because the rotenone compounds contained in the roots are higher than the branches and leaves, so it works optimally as a contact poison and stomach poison. According to Kardinan [23], the active ingredient of rotenone works as a stomach poison and contact poison which is selective to insects.

Brown planthopper is plant-sucking and liquid-sucking insects [5]. The mechanism of insecticide stomach poison is by killing the target insect by entering into digestion through food. Insecticides enter the digestive organs of insects and are absorbed by the intestinal wall, and they are transplanted to the nerve centers of insects and respiratory organs and poison stomach cells [25]. This is also supported because the treatment of botanical insecticides in the roots part gives a lethal meantime (LT50) of 17.33 hours after application, faster than other treatments, so that daily mortality on the first day becomes higher.

The second and third daily mortality in the treatment of botanical insecticides from all sources has decreased. This is because the number of living brown planthopper decreases. This is also because botanical insecticides from plant-based matter have disadvantages such as biodegradability. Dadang and Prijono [16] support that there are some deficiencies of botanical insecticides, including the low botanical insecticides persistence, so that repeated applications are needed when the population of pests is high.

\section{Total mortality (\%)}

Observation of the total mortality of brown planthopper after analysis of variance shows that the treatment of botanical insecticides in some parts of the tuba root plant significantly affects the total mortality of brown planthopper. LSD further test results at the level of 5\% can be seen in Table 3 .

TABLE III

TOtal Mortality of Brown Planthopper AFter APPliCATION OF BOTANICAL INSECTICIDES FROM VARIOUS PARTS OF THE TUBA ROOT PLANT (\%)

\begin{tabular}{cc}
\hline Part of Tuba Root Plant & Average (hour) \\
\hline Root & $100,00 \mathrm{a}$ \\
Branch & $80,00 \mathrm{~b}$ \\
Leaf & $73,33 \mathrm{c}$ \\
\hline
\end{tabular}

Note: The number on the lane followed by lowercase letters are not significantly different according to the LSD test at the 5\% level.

Table 3. shows that the botanical insecticide test for some parts of the tuba root plant had a significant effect on the total mortality of brown planthopper. Botanical insecticide treatment from the root causes total mortality of brown 
planthopper by $100 \%$ and significantly different from the branches and leaves. Botanical insecticide from the branches part showed total mortality of $80 \%$ and significantly different from the leaves with mortality of $73.33 \%$ until the end of the observation. This is due to the influence of the poison ability and brown planthopper's response to the botanical insecticide of the root parts, which has high rotenone toxin content compared to other treatments. This is supported by Yoon [20] that the most critical toxic substance contained is rotenone. Besides, there are deguelin, toxsicarol, alkaloids, saponins, and polyphenols in the tuba root plant.

Gunawaty's research results [37] showed that the application of tuba root powder extract with a water solvent with a concentration of $10 \%$ causes mortality of stinky rice bug as much as $98 \%$. Tuba root extract with a concentration of $10 \mathrm{~g}$ can control the brown planthopper pest in rice plants by $90 \%$ in the laboratory [29]. The results of research Kinansi et al. [19] also showed that the ethanol extract of tuba plant roots effectively killed $50 \% P$. americana at 6.505 hours at a concentration of $3 \mathrm{~g} / 100 \mathrm{ml}$, while LT90 at 11.372 at a concentration of $9 \mathrm{~g} / 100 \mathrm{ml}$. The results of Adharini's research [38] also showed that spraying the ethanol extract of tuba plant roots in termites with a concentration of 5\% gave results as good as spraying a concentration of $10 \%$ because termite mortality reached the same mortality of $100 \%$.

The application of botanical insecticide from the root part is effective in controlling brown planthopper. This is due to the total mortality of brown planthopper has been able to reach $100 \%$. These results are consistent with the opinion of Dadang and Prijono [16], botanical pesticides to be effective as pesticides if the treatment with these extracts can result in a mortality rate of over $80 \%$.

\section{CONCLUSION}

The conclusion based on the results of this study showed that the tuba roots from the roots part are the best to be used as botanical pesticides against brown planthopper pests in rice plants. The application of root extract caused an initial death of 2.33 hours after application, 17.33 hours after application of lethal meantime (LT50), with a total mortality rate of $100 \%$.

\section{ACKNOWLEDGMENT}

We are grateful to the Riau University Institute of Research and Community Services (LPPM UNRI) for the funding support of this research through the Research Grant Program in the year 2019.

\section{REFERENCES}

[1] Central Statistic Agency of Riau Province, Riau Province in Figures 2018. Riau: Central Statistics Agency of Riau Province, 2019.

[2] N. V. Krishnaiah, "A Global Perspective of Rice Brown Planthopper Management ?--Crop-Climatic Requirement," Int. J. Mol. Zool., vol. 4, no. 2, pp. 9-18, 2014, doi: 10.5376/ijmz.2014.04.0002.

[3] E. H. Iswanto, U. Susanto, and A. Jamil, "Developments and Challenges of Resistant Varietal Breeding Program in Brown Planthopper Management in Indonesia," J. Penelit. dan Pengemb. Pertan., vol. 34, no. 4, pp. 187-193, 2015, doi: 10.21082/jp3.v34n4.2015.p187-193.

[4] R. C. Saxena, and A. A. Barrion. "Biotypes of the Planthopper Nilaparvata lugens (Stal.)" Korean Journal of Plant Protection, vol. 22, no. 2, pp. 52-66, 1983.

[5] T. Watanabe, and H. Kitagawa. "Photosynthesis and Translocation of Assimilates in Rice Plants Following Phloem Feeding by the
Planthopper Nilaparvata lugens (Homoptera: Delphacidae)" J. Econ. Entomol., vol. 93, no. 4, pp. 1192-1198, 2000.

[6] S. E. Baehaki and I. M. J. Mejaya, "Wereng Cokelat sebagai Hama Global Bernilai Ekonomi Tinggi dan Strategi Pengendaliannya," Iptek Tanam. Pangan, vol. 9, no. 1, pp. 1-12, 2014.

[7] F. X. Wagiman, H. Fauzana, and K. Y. Prasetyani, "Wood fly-ash toxicity against Nilaparvata lugens and its predator comlex," $J$. Perlindungan Tanam. Indones., vol. 17, no. 1, pp. 41-46, 2011.

[8] S. E. Baehaki, "Perkembangan Biotipe Hama Wereng Coklat pada Tanaman Padi," Iptek Tanam. Pangan, vol. 7, no. 1, pp. 8-17, 2012.

[9] B. Nurbaeti, I. A. Diratmaja, and S. Putra, Hama Wereng Coklat (Nilaparvata lugens Stal) dan Pengendaliannya. Lembang, 2010.

[10] Rustam, "Production Performance and Plant Pest Organisms for Rice, Corn and Soybeans Crops in Riau Province," J. Agroteknologi Trop., vol. 5, no. 1, pp. 39-54, 2016.

[11] K. Untung, Pengantar Pengelolaan Hama Terpadu. Yogyakarta: Gadjah Mada University Press, 2000.

[12] Sutrisno, "Heritabilitas Resistensi terhadap Insektisida pada Wereng Batang Cokelat, Nilparvata lugens (Stal) di Indonesia seleksi," War. Biog., vol. 10, no. 2, pp. 7-9, 2014.

[13] Melhanah, Witjaksono, and Y. A. Trisyono, "Selection Toward Resistance to Fipronil in Brown Planthopper," Jurnal Perlindungan Tanaman Indonesia, vol. 8, no. 2. pp. 107-113, 2002.

[14] E. S. Ratna, A. S. Firmansyah, and Rahmini, "Pengaruh Dosis Subletal Imidakloprid Terhadap Kesintasan Populasi Wereng Coklat Pada Varietas Padi Rentan Dan Tahan," J. Hama Dan Penyakit Tumbuh. Trop., vol. 16, no. 1, pp. 51-60, 2016, doi: 10.23960/j.hptt.11651-60.

[15] M. Nanthakumar, V. J. Lakhsmi, V. S. Bhusan, S. Balachandran and M. Mohan, "Decrease of Rice Plant Resistance and Induction of Hormosis and Carboxylesterase Titre in Brown Planthopper by Xenobiotics Pesticide" Biochemistr Physiology, vol. 02, 2012.

[16] Dadang dan D. Prijono. Insektisida Nabati: Prinsip, Pemanfaatan dan Pengembangan. Bogor: Departemen Proteksi Tanaman IPB, 2008

[17] P. P., Hien, H. Gortnizka and Kraemer, "Rotenone Potential and Prospect for Sustanable Agruculture" Journal Omonrice, vol. 11, pp. 83-92, 2003.

[18] R. Rahmawasiah, "Pengaruh Pemberian Ekstrak Akar Tuba untuk Mengendalikan Hama Kutu Daun Aphis gossypii pada Tanaman Kacang Hijau (Vigna radiata L .)," J. Perbal, vol. 5, no. 3, pp. 41-48, 2017.

[19] P. B. Kaufman, A. Kirakosyan, M. McKenzie and P, Hoyt JE, Li C. The uses of plant natural products by humans and risks associated with their use dalam: Natural Products from Plants. Boca Raton (US): CRC Press. 2006.

[20] A. S. Yoon, "Extraction of Rotenone from Derris elliptica and Derris malaccensis by Pressurized Liquid Extraction Compared with Maceration" Journal of Cromatography A. Elsaiver, vol. 1125, pp. 172-176, 2006.

[21] Kuncoro. Tanaman yang Mengandung Zat Pengganggu. Jakarta: CV Amalia, 2006

[22] F. C. B., Ginting, Siswanto, I. M. Merdana. "Uji Toksisitas Ekstrak Akar Tuba (Derris elliptica) Secara Topikal pada Kulit Anjing Lokal" Jurnal Indonesia Medicus Veterinus, vol. 4, no. 2, pp. 97-103, 2015.

[23] A. Kardinan, Pestisida Nabati Ramuan dan Aplikasi. Jakarta: Penebar Swadaya, 2004.

[24] M. B. Isman, "Botanical insecticides, deterrents, and repellents in modern agriculture and an increasingly regulated world," Annu. Rev. Entomol., vol. 51, pp. 45-66, 2006, doi 10.1146/annurev.ento.51.110104.151146.

[25] R. C. Tarumingkeng, Insektisida: Sifat Mekanis Kerja dan Dampak Penggunaannya. Yogyakarta: Kanisius, 1992.

[26] L. Wibowo, Indriyati, Solikhin, "Uji Aplikasi Ekstrak Kasar Buah Pinang, Akar Tuba, Patah Tulang dan Daun Nimba terhadap Keong Emas (Pomacea sp.) di Rumah Kaca” Jurnal HPT Tropika, vol. 8, no. 1, pp. 17-22, 2008.

[27] Nurman. Concentrations Test of Tuba Root Extract (Derris elliptica Benth.) for Controlling White Lice Pest Paracoccus marginatus (Hemiptera: Pseudococcidae) on Papaya. Skripsi, Universitas Riau, Pekanbaru, Riau, Indonesia. 2011.

[28] D. Y. Sistomo, Tests of Some Concentrations of Tuba Root Flour (Derris elliptica Benth) on Mortality of Aphis glycines Matsumura (Homoptera: Aphididae) Aphids on Soybean Plants. Skripsi, Universitas Riau, Pekanbaru, Riau, Indonesia. 2013.

[29] Kastina, Z. V. K. Concentration Test of Some Vegetable Pesticides on the Mortality of Brown Planthopper Pests (Nilaparvata lugens Stal.). Skripsi, Universitas Riau, Pekanbaru, Riau, Indonesia. 2018.

[30] R. R. Kinansi, S. W. Handayani, D. Prastowo, A. O. Y. Sudarno, 
"Efektifitas ekstrak etanol akar tuba (Derris elliptica) terhadap kematian Periplaneta americana dengan metode spraying" Jurnal BALABA, vol. 14, no. 2, pp. 147-158, 2018.

[31] S. Atun, "Metode Isolasi dan Identifikasi Struktural Senyawa Organik Bahan Alam," J. Konserv. Cagar Budaya Borobudur, vol. 8, no. 2, pp 53-61, 2014, doi: 10.33374/jurnalkonservasicagarbudaya.v8i2.132.

[32] H. Fauzana, F. Wagiman, and E. Martono, "Gangguan fisiologis wereng batang padi coklat akibat pemberian abu terbang batubara," $J$. Entomol. Indones., vol. 11, no. 1, pp. 27-33, 2014, doi: 10.5994/jei.11.1.27.

[33] E. Yennie, S. Elystia, A. Kalvin, and M. Irfhan, "Pembuatan Pestisida Organik Menggunakan Metode Ekstraksi Dari Sampah Daun Pepaya Dan Umbi Bawang Putih," J. Tek. Lingkung. UNAND, vol. 10, no. 1, pp. 46-59, 2013, doi: 10.25077/dampak.10.1.46-59.2013.
[34] H. Natawigena, Dasar-dasar Perlindungan Tanaman, Bandung: Triganda Karya, Bandung, 1993.

[35] A. Kardinan, "Kearifan Lokal Dalam Pengendalian Hama," Pengemb. Inov. Pertan., vol. 4, no. 4, pp. 262-278, 2011.

[36] B. Martono, E. Hadipoentyanti, D. Laba, U. B. Penelitian, T. Rempah, and D. Obat, "Plasma Nutfah Insektisida Nabati," Perkemb. Teknol. TRO, vol. 16, no. 1, pp. 43-59, 2004.

[37] Y. S. Gunawaty, Tests of Several Botanical Insecticide Extracts in Controlling Swallow Pests (Leptocorisa oratorius Fabricius) (Hemiptera: Alydidae) on Gogo Rice Plants (Oryza sativa L.). Skripsi, Universitas Riau, Pekanbaru, Riau, Indonesia. 2014.

[38] Adharini, G. Test the efficacy of tuba root extract (Derris elliptica Benth) for control of termites Coptotermes curvignathus holmgren. Skripsi. IPB, Bogor, Indonesia, Apr. 2008. 